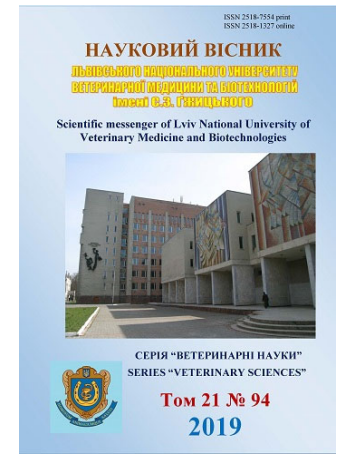

Науковий вісник Аьвівського національного університету ветеринарної медицини та біотехнологій імені С.3. Гжицького. Серія: Ветеринарні науки

Scientific Messenger of Lviv National University of Veterinary Medicine and Biotechnologies. Series: Veterinary sciences

ISSN 2518-7554 print ISSN 2518-1327 online doi: $10.32718 /$ nvlvet9433

http://nvlvet.com.ua

UDC 619:616.5:619:616-021:591.478:636.2

\title{
The influence of conditions of detention the hoof and the development of aseptic inflammation of the producing layer of the base of the skin soles hooves in the cows
}

\author{
N.M. Khomyn ${ }^{1}$, A.R. Mysak ${ }^{1}$, S.V. Tsisinska ${ }^{1}$, V.V. Pritsak ${ }^{1}$, Yu.M. Lenyo ${ }^{1}$, M.M. Khomyn ${ }^{2}$ \\ ${ }^{1}$ Stepan Gzhytskyi National University of Veterinary Medicine and Biotechnologies Lviv, Ukraine \\ ${ }^{2}$ Institute of Animal Biology NAAS, Lviv, Ukraine
}

Article info

Received 02.05.2019

Received in revised form 03.05 .2019

Accepted 04.06.2019

Stepan Gzhytskyi National University of Veterinary Medicine and Biotechnologies Lviv,

Pekarska Str., 50, Lviv,

79010, Ukraine.

Tel.: +38-067-894-17-12

E-mail:nadiakhomyn@ukr.net

Institute of Animal Biology of NAAS, Stusa Str., 38, Lviv,

79000, Ukraine.
Khomyn, N.M., Mysak, A.R., Tsisinska, S.V., Pritsak, V.V., Lenyo, Yu.M., \& Khomyn, M.M. (2019). The influence of conditions of detention the hoof and the development of aseptic inflammation of the producing layer of the base of the skin soles hooves in the cows. Scientific Messenger of Lviv National University of Veterinary Medicine and Biotechnologies. Series: Veterinary sciences, 21(94), 179-183. doi: 10.32718/nvlvet9433

Violation of the conditions of animals keeping and the lack of proper level of veterinary and sanitary culture on farms does not allow to achieve a balance between the organism of the cattle and the environment of its stay. The uneven distribution of body weight on the surface of the sole caused by keeping animals on a rough floor promotes the emergence of producing corns, stretching of the tendons and ligaments, slippery flooring leads to the fall of animals and the occurrence of various injuries, in particular, fractures of the limbs, tensile bond, capsule of the joint, excessively hard floor - to excessive erosion of the horn of the sole, etc. In such herds it is difficult to maintain animal health at the proper level and prevent the occurrence of, in particular, aseptic pododermatitis. The article deals with the results on the dissemination of aseptic pododermatitis in cows for the presence of animals on wooden and reinforced concrete slit floors during the winter and standstill period of containment. It has been established that aseptic pododermatitis in cows on reinforced concrete slit floor is registered in $71.6 \%$ of cases, while on wooden - only $28.4 \%$. In the hoof horn of the thoracic and pelvic extremities of the cows, with aseptic pododermatitis, the amount of moisture decreased by 8.2 and 9.3\% respectively, the concentration of SH-groups increases by 10.6 and $15.8 \%$, with a possible decrease in the content of calcium, sulfur, cuprum and zinc; decreases the hoof horn density and resistance to abrasion of the epithelium of the hooves of the pelvic limbs by 1.6 and $18.0 \%$, as well as the intensity of the abrasion sole hooves of the thoracic and pelvic limbs is increased by 7.5 and $20.0 \%$, which helps to reduce the growth of the epidermis of the sole. Consequently, changes in certain biochemical and biophysical indices of hoof horns of cows suffering from aseptic pododermatitis, which were held on the reinforced concrete slit, indicate a deterioration in the quality of the epidermal hooves and excessive erosion of the sole, which is one of the causes of the occurrence and development of aseptic pododermatitis in cows.

Key words: cows, hoof horn, mineral substances, biophysical parameters, biochemical indices, conditions of detention, state of floor, pododermatitis.

\section{Вплив умов утримання на стан копитець та розвиток асептичного запалення продукуючого шару основи шкіри підошви копитець у корів}

\author{
Н.М. Хомин ${ }^{1}$, А.Р. Мисак ${ }^{1}$, С.В. Цісінська ${ }^{1}$, В.В. Прицак ${ }^{1}$ Ю.М. Леньо ${ }^{1}$, М.М. Хомин ${ }^{2}$ \\ ${ }^{1}$ Львівський національний університет ветеринарної медиџини і біотехнології імені С.3. Гжиџького, \\ м. Львів, Україна \\ ${ }^{2}$ Інститут біології тварин НААН, м. Львів, Україна
}


Порушення умов утримання тварин та відсутність належного рівня ветеринарно-санітарної культури на фермах не дає можливості досягати балансу між організмом худоби і середовищем ї̈ перебування. Нерівномірний розподіл ваги тіла на поверхню підошви, викликаний утриманням тварин на нерівній підлозі сприяє появі наминок, розтягу сухожилків та зв'язок, слизька підлога призводить до падіння тварин та виникнення різноманітних травм, зокрема, переломів кінцівок, розривів зв'язок, капсули суглобу, надмірно тверда підлога - до надмірного стирання рогу підошви тощя. У таких стадах важко підтримувати здоров'я тварин на належному рівні та запобігати виникненню, зокрема асептичного пододерматиту. У статті наведені результати досліджень щзодо поширення асептичного пододерматиту у корів за умов утримання тварин на дерев'яних та залізобетонних щілинних підлогах у зимово-стійловий період. Встановлено, щзо асептичний пододерматит у корів, яких утримують на залізобетонній щілинній підлозі реєструють у 71,6\% випадків, тоді як на дерев'яній - лише у 28,4\%. У копитцевому розі грудних $і$ тазових кінцівок корів, хворих на асептичний пододерматит зменшується кількість вологи відповідно на 8,2 та 9,3\%, збільшується концентрація SH-груп на 10,6 та 15,8\% за вірогідного зменшення умісту кальиію, сульфуру, купруму та циинку; знижується щзільність копитиевого рогу та опір до стирання епідермісу копитець тазових кінцівок на 1,6 та 18,0\%, а також підвищується інтенсивність стирання підошви копитещь грудних і тазових кіниівок на 7,5 та 20,0\%, що сприяє зменшенню наростання епідермісу підошви. Отже, зміни окремих біохімічних та біофізичних показників копитцевого рогу корів, хворих на асептичний пододерматит, яких утримували на залізобетонній щілинній підлозі свідчать про погіршення якості епідермісу копитець та надмірне стирання підошви, щзо $\epsilon$ однією з причин виникнення і розвитку у них асептичного пододерматита.

Ключові слова: корови, копитцевий ріг, мінеральні речовини, біофізичні показники, біохімічні показники, умови утримання, стан підлог, пододерматит.

\section{Вступ}

У зимово-стійловий період тварини знаходяться у приміщенні доволі довгий період часу, тому стан здоров'я та продуктивність худоби у багатьох випадках залежать від тих умов, які створені на фермах. Порушення санітарно-гігієнічних вимог щодо мікроклімату у приміщеннях, стану і конструкції підлог, тощо сприяють виникненню різних захворювань, особливо опорно-рухового апарату, що знижує продуктивність корів та наносить значні економічні збитки господарствам (Povazhenko \& Borisevich, 1987; Pozhyvil, 1994).

Підлоги - це та частина приміщення, з якою тварина упродовж стійлового періоду утримання постійно контактує. Очевидно, що від якості підлоги залежить і вплив іiі на опорно-руховий апарат тварини. Тому підлога повинна бути теплою, вологонепроникною, сухою, не слизькою, не твердою, міцною і разом 3 тим добре і легко піддаватись очищенню і дезинфекції. На такій підлозі тварини довше відпочивають у положенні лежачи, їх м'язи і сухожилки менше втомлюються, а це сприяє підвищенню продуктивності худоби (Saievych et al., 1994; Yarygin, 2004).

На умови утримання, як одну 3 провідних причин у виникненні захворювань пальців, зокрема й копитець у худоби вказує ряд авторів (Baykenov, 2001; Mastyko, 2005; Borysevych et al., 2007). Вони вважають, що основною причиною, яка призводить до порушення опорно-силових взаємозв'язків у структурах копитець $є$ невдалі конструкції решітчастих підлог, які спричиняють перерозподіл ваги тіла на підошву копитець, тобто перевантаження одних частин підошви і звільнення від опори інших, що провокує нерівномірне стирання копитцевого рогу та, у кінцевому результаті, внаслідок порушення крово- і лімфообігу, викликає виникнення захворювань копитець.

Інші автори стверджують, що розвитку захворювань сприяють адинамія, підвищена вологість у приміщеннях, мацерація рогу копитець, а також прояв статевих рефлексів (Kurtyak, 1991; Molokanov, 1993; Kogut \& Borysevych, 2003). Загалом сукупність цих та інших етіологічних чинників призводить до захворю- вань опорно-рухового апарату, зокрема до виникнення і розвитку асептичних пододерматитів.

Існуюче уявлення про те, що асептичні пододерматити завжди закінчуються самовидужанням у корні невірно. Як відомо, така патологія є пусковим механізмом для розвитку більш важких хворобливих процесів, особливо у тих випадках, коли етіологічний чинник діє тривалий період часу та мають місце антисанітарні умови утримання тварин.

Мета роботи. За змінами біохімічних показників та фізико-механічних параметрів епідермісу копитець встановити вплив умов утримання на стан копитцевого рогу та виникнення асептичного запалення основи шкіри копитець у корів.

\section{Матеріал і методи досліджень}

Дослідження проводили у господарствах Львівської області на коровах чорно-рябої породи у зимовостійловий період за прив'язного утримання тварин. Було сформовано 2 групи корів (контрольна і дослідна) по 5 тварин у кожній, підібраних за принципом аналогів щодо віку, маси тіла, продуктивності; контрольна група - клінічно здорові тварини, дослідна корови $з$ асептичним пододерматитом. Були проведені біохімічні та біофізичні дослідження копитцевого рогу у нормі та за асептичного пододерматиту. Так, уміст вологи визначали стабільним висушуванням зразка до постійної ваги, кількість золи - шляхом озолення зразка у муфельній печі, уміст жиру - на апараті Соксклета, шляхом екстрагування жиру 3 досліджуваного матеріалу за допомогою органічних розчинників та білка - на апараті Кьєльдаля (Lebedev \& Usovich, 2006; Vlizlo et al., 2012). Визначення SHгруп (Makar, 1977) та Сульфуру проводили хімічними методами, умісту Кальцію, Купруму, Цинку та Кобальту - методом атомно-абсорбційної спектрофотометрії (Baykenov, 2001; Lebedev \& Usovich, 2006; Lvov, 2006; Vlizlo et al., 2012), а Фосфору - фотоколориметричним методом за А.Т. Усовичем (Makar, 1977). Крім того, щільність копитцевого рогу визначали шляхом гідростатичного зважування, твердість - за методом Бринеля (Iveronova, 2007), а ріст і сти- 
рання - за допомогою насічок, нанесених на зачіпну частину стінки копитець (Iveronova, 2007).

Отримані числові дані обробляли за допомогою стандартного пакету статистичних програм Microsoft EXCEL.

\section{Результати та їх обговорення}

Як показали дослідження, частота виникнення асептичного пододерматиту залежить від умов утримання тварин, зокрема, від типу підлог, на яких худоба перебуває під час зимово-стійлового утримання. Тривалий клінічний контроль за копитцями тварин у цей період дозволив встановити, що лише у поодиноких випадках асептичні пододерматити проходять безслідно; у більшості вони переходять у гнійні пододерматити.

Результатами досліджень, проведених протягом трьох років встановлено, що за утримання тварин на дерев'яній підлозі, асептичний пододерматит реєстрували у 39 корів, тоді як на залізобетонній щілинній - у 99 тварин (рис. 1).

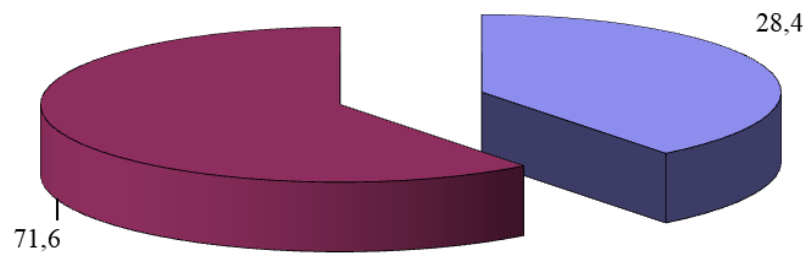

口Дерев'яна 口Залізобетонна щілинна

Рис. 1. Частота виникнення асептичного пододерматиту у корів залежно від типу підлог, $\mathrm{n}=138$

\section{Таблиця 1}

Біохімічні показники копитцевого рогу, $\mathrm{M} \pm \mathrm{m}, \mathrm{n}=5$
Очевидно, тип підлог та їх конструкція сприяє виникненню асептичного пододерматиту, оскільки тепла і нежорстка дерев'яна підлога сприятливіше впливає на підошву копитець, ніж залізобетонна щілинна.

Враховуючи те, що під час стійлового утримання тварин основне навантаження припадає на статичний апарат, вплив підлоги на підошву підвищується у багато разів і нерівна, щілинна підлога хоча й економічно вигідна, однак фізіологічно не виправдовує себе. Тиск на окремі елементи підошви копитець нерівномірний у зв'язку із зменшенням площі контакту 3 поверхнею опори і тому незначні супутні етіологічні фактори можуть спровокувати у цих місцях розвиток запального процесу (Rodin \& Tyurin, 1992).

Результати наших досліджень узгоджуються 3 даними інших авторів, які стверджують, що розвитку захворювання сприяє невдала конструкція щілинної підлоги і неправильне розміщення решіток відносно годівниць та невідповідність розмірів елементів решіток щілинної підлоги віку і масі тварин (Churkina \& Moskalenko, 2007).

Для поглибленного вивчення впливу типу підлог на стан підошви були проведені біохімічні та біофізичні дослідження епідермісу копитець у худоби.

Як показали біохімічні дослідження копитцевого рогу, вміст вологи, золи, жиру і білка змінювалися залежно від умов утримання (табл. 1).

Зокрема, суттєві зміни спостерігали відносно вмісту вологи у епідермісі підошви копитець тварин, які перебували на залізобетонній щілинній підлозі.

\begin{tabular}{|c|c|c|c|c|}
\hline \multirow{6}{*}{ Показники } & \multicolumn{4}{|c|}{ Підлога } \\
\hline & \multicolumn{2}{|c|}{ дерев'яна } & \multicolumn{2}{|c|}{ залізобетонна щілинна } \\
\hline & \multicolumn{4}{|c|}{ Група } \\
\hline & \multicolumn{2}{|c|}{ контрольна } & \multicolumn{2}{|c|}{ дослідна } \\
\hline & \multicolumn{4}{|c|}{ Кінцівка } \\
\hline & грудна & тазова & грудна & тазова \\
\hline Волога, \% & $31,2 \pm 2,24$ & $32,7 \pm 1,99$ & $23,0 \pm 1,14^{*}$ & $23,4 \pm 2,32^{*}$ \\
\hline Зола, \% & $1,19 \pm 0,054$ & $1,21 \pm 0,042$ & $1,18 \pm 0,053$ & $1,14 \pm 0,029$ \\
\hline Жир, \% & $0,06 \pm 0,009$ & $0,05 \pm 0,007$ & $0,04 \pm 0,004$ & $0,05 \pm 0,006$ \\
\hline Білок, \% & $91,8 \pm 1,54$ & $91,4 \pm 1,66$ & $90,5 \pm 2,01$ & $90,1 \pm 6,19$ \\
\hline Кальцій, г/кг & $1,80 \pm 0,070$ & $1,78 \pm 0,54$ & $1,60 \pm 0,035^{*}$ & $1,64 \pm 0,012^{* *}$ \\
\hline Фосфор, г/кг & $1,15 \pm 0,034$ & $1,12 \pm 0,025$ & $1,17 \pm 0,032$ & $1,14 \pm 0,064$ \\
\hline Сульфур, г/кг & $18,20 \pm 0,159$ & $18,17 \pm 0,215$ & $17,29 \pm 0,297^{*}$ & $17,21 \pm 0,277^{*}$ \\
\hline Купрум, мг/кг & $28,16 \pm 0,762$ & $28,12 \pm 0,659$ & $23,47 \pm 1,536^{*}$ & $23,35 \pm 0,754^{* *}$ \\
\hline Цинк, мг/кг & $18,80 \pm 0,460$ & $18,82 \pm 0,394$ & $16,92 \pm 0,487^{*}$ & $16,87 \pm 0,279^{* *}$ \\
\hline Кобальт,мг/кг & $9,34 \pm 0,270$ & $9,51 \pm 0,294$ & $8,81 \pm 0,186$ & $8,78 \pm 0,194$ \\
\hline SН-групи, мкмоль/г & $28,4 \pm 0,16$ & $27,8 \pm 0,95$ & $31,4 \pm 0,99 *$ & $32,2 \pm 1,02 *$ \\
\hline
\end{tabular}

Так, волога копитцевого рогу грудних кінцівок корів дослідної групи на 8,2\%, а тазових - на 9,3\% вірогідно нижча порівняно з показниками тварин контрольної групи і становить відповідно 23,0 \pm 1,14 проти $31,2 \pm 2,24$ та $23,4 \pm 2,32$ проти $32,7 \pm 1,99 \%$. Крім того, спостерігаються зміни і щодо вмісту мінеральних речовин, зокрема має місце вірогідне зменшення концентрації кальцію, сульфуру, купруму та цинку у копитцевому розі грудних кінцівок у корів на 11,1 , $5,0,16,7$ та 10\%, а в епідермісі копитець тазових кін- 
цівок - відповідно на 7,9, 5,3, 17,0 та 10,4\% за незначного зменшення вмісту кобальту.

Зміни стосовно вмісту макро-і мікроелементів та води у копитцевому розі тварин дослідної групи свідчать про погіршення якості епідермісу копитець у зимово-стійловий період. Підтвердженням цього є збільшення у копитцевому розі концентрації SH-груп, які є важливим інтегральним показником якості твердих кератинів. Як показують результати досліджень, вміст SH-груп у копитцевому розі грудних і тазових кінцівок тварин дослідної групи був на 10,6 та 15,8\% вище контрольного показника, що в абсолютних величинах становить $31,4 \pm 0,99$ проти $28,4 \pm 0,16$ та
32,2 \pm 1,02 проти 27,8 \pm 0,95 мкмоль/г. Вищенаведені відмінності окремих біохімічних показників копитцевого рогу кінцівок корів дослідної групи, очевидно, вказують на погіршення якості епідермісу копитець, що було більш виражено у копитцевому розі тазових кінцівок.

Підтвердженням результатів біохімічних досліджень копитцевого рогу корів слугують дані, отримані за визначення його фізико-механічних параметрів. Дослідження показали, що величина біофізичних показників копитцевого рогу також змінюється залежно від умов утримання, тобто стану та якості підлоги (табл. 3).

Таблиця 3

Біофізичні показники копитцевого рогу, $\mathrm{M} \pm \mathrm{m}, \mathrm{n}=5$

\begin{tabular}{|c|c|c|c|c|}
\hline \multirow{6}{*}{ Показники } & \multicolumn{4}{|c|}{ Підлоги } \\
\hline & \multicolumn{2}{|c|}{ дерев'яна } & \multicolumn{2}{|c|}{ залізобетонна щілинна } \\
\hline & \multicolumn{4}{|c|}{ Група } \\
\hline & \multicolumn{2}{|c|}{ контрольна } & \multicolumn{2}{|c|}{ дослідна } \\
\hline & \multicolumn{4}{|c|}{ Кінцівка } \\
\hline & грудна & тазова & грудна & тазова \\
\hline 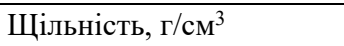 & $1,192 \pm 0,012$ & $1,186 \pm 0,004$ & $1,180 \pm 0,004$ & $1,167 \pm 0,002 * *$ \\
\hline Твердість, кгс/см² & $148,4 \pm 5,65$ & $147,8 \pm 2,64$ & $147,5 \pm 4,29$ & $144,6 \pm 3,46$ \\
\hline Опір до стирання, об/мм & $126,4 \pm 3,47$ & $119,2 \pm 5,13$ & $105,6 \pm 6,12 *$ & $97,7 \pm 6,35^{*}$ \\
\hline Ріст, мм/міс & $8,0 \pm 0,43$ & $7,6 \pm 0,27$ & $7,5 \pm 0,26$ & $8,0 \pm 0,22$ \\
\hline Стирання, мм/міс & $6,7 \pm 0,12^{\bullet}$ & $6,5 \pm 0,24^{\bullet}$ & $7,2 \pm 0,006^{* *}$ & $7,8 \pm 0,26^{* *}$ \\
\hline
\end{tabular}

Примітка: * - $\mathrm{P}<0,05,-\mathrm{P}<0,01-$ вірогідна різниця порівняно з показниками контрольної групи; $-\mathrm{P}<0,05-$ вірогідна різниця між ростом і стиранням

У копитцевому розі грудних і тазових кінцівок тварин, яких утримують на дерев'яній підлозі, вірогідних змін з боку більшості біофізичних показників не спостерігається, за винятком співвідношення між ростом і стиранням. Так, інтенсивність росту епідермісу копитець грудних кінцівок була на 19,4\% вірогідно вищою від стирання, що становить 8,0 $\pm 0,43$ проти $6,7 \pm 0,12 \mathrm{Mм} /$ міс, а на тазових - на $16,9 \%$, тобто $7,6 \pm 0,27$ проти 6,5 $\pm 0,24$ мм/міс.

Натомість, у копитцевому розі тварин дослідної групи, які перебувають на залізобетонній щілинній підлозі мають місце зміни, які полягають у зменшенні величини більшості біофізичних показників, особливо епідермісу тазових кінцівках. Відзначається на 1,6 та 18,0\% відповідно зменшення щільності та опору до стирання за умов незначного зниження твердості порівняно з копитцевим рогом тазових кінцівок тварин контрольної групи. Серед вище перелічених біофізичних показників епідермісу грудних кінцівок у цієї групи тварин вірогідні зміни мають місце лише щодо опору до стирання, величина якого на 16,5\% менша відносно аналогічного показника у тварин контрольної групи.

Інтенсивність стирання копитцевого рогу грудних кінцівок у тварин дослідної групи була вищою відповідно на 7,5, а тазових - на 20,0\% порівняно 3 контрольним показником, що, у свою чергу, впливає на зменшення інтенсивності відростання копитцевого рогу у тварин цієї групи.

Згідно проведених досліджень відростання копит- цевого рогу порівняно із стиранням на грудних кінцівках і тазових кінцівках тварин контрольної групи вірогідно більше на 19,4 та 16,9\%, тоді як корів дослідної - лише на 4,2 та 2,6\%, що в абсолютних величинах складає відповідно $8,0 \pm 0,43$ проти $6,7 \pm 0,12$ та $7,6 \pm 0,27$ проти $6,5 \pm 0,24$ мм/міс та 7,5 $\pm 0,26$ проти 7,2 $\pm 0,006$ та 8,0 \pm 0,22 проти 7,8 \pm 0,26 мм/міс.

Виходячи 3 результатів досліджень біофізичних властивостей копитцевого рогу корів, яких утримували на різних типах підлог, можна зробити висновок, що залізобетонна щілинна підлога, порівняно 3 дерев'яною негативно впливає на стан копитцевого рогу, оскільки, йморівно, іiі конструкція і особливо залізобетонне покриття сприяє зниженню щільності та опору до стирання. У результаті цього інтенсивність стирання епідермісу підошви копитець корів на залізобетонній щілинній підлозі значно вища.

Отже, зміни біохімічних показників копитцевого рогу, які полягають, в основному, у вірогідному зменшенні умісту вологи, Кальцію, Сульфуру, Купруму та Цинку, а також, очевидно, конструктивні недоліки щілинних підлог викликають погіршення фізикомеханічних властивостей рогової тканини, особливо тазових кінцівок. На тлі цього порушується нормальне стирання рогу підошви і у кінці зимово-стійлового періоду виникають різноманітні ортопедичні патологічні зміни, які призводять до розвитку, на нашу думку, асептичного пододерматиту. 


\section{Висновки}

1. Асептичний пододерматит у корів у зимовостійловий період утримання на залізобетонній щілинній підлозі реєструють у 71,6\% випадків, тоді як на дерев'яній - лише у $28,4 \%$.

2. У копитцевому розі грудних і тазових кінцівок корів, хворих на асептичний пододерматит зменшується кількість вологи відповідно на 8,2 та 9,3\%, збільшується концентрація SH-груп на 10,6 та $15,8 \%$ за вірогідного зменшення умісту Кальцію, Сульфуру, Купруму та Цинку, знижується щільність копитцевого рогу та опір до стирання епідермісу копитець тазових кінцівок на 1,6 та 18,0\%, а також підвищується інтенсивність стирання підошви копитець грудних і тазових кінцівок на 7,5 та 20,0\%, що сприяє зменшенню наростання епідермісу підошви.

3. Зміни окремих біохімічних та біофізичних показників копитцевого рогу корів, хворих на асептичний пододерматит, яких утримували на залізо-бетонній щілинній підлозі свідчать про погіршення якості епідермісу копитець та надмірне стирання підошви.

Перспективи подальших досліджень. Дослідження будуть направлені на пошук нових методів покращення якості копитцевого рогу корів 3 метою попередження виникнення $\mathrm{i}$ розвитку асептичного пододерматиту.

\section{References}

Baykenov, M.T. (2001). Diagnostika. profilaktika i lecheniye zabolevaniy kopytets u korov. Avtoref. diss... kand. vet. nauk. Troitsk, 22 (in Russian).

Borysevych, V.B., Borysevych, B.V., Petrenko, O.F., \& Khomyn, N.M. (2007). Veterynarna ortopediia: khvoroby kopyt i kopytets. Kyiv: TOV "Ukrzolotopostach" (in Ukrainian).

Churkina, N., \& Moskalenko, S. (2007). Vliyaniye usloviy soderzhaniya na stroyeniye rogovogo bashmaka krupnogo rogatogo skota. Trudy Kharkovskogo s.-kh. in-ta. Kharkov, 236, 134-138 (in Russian).

Iveronova, V.I. (2007). Mekhanika i molekulyarnaya fizika: fizicheskiy praktikum. M.: Vysshaya shkola (in Russian).

Kogut, N., \& Borysevych, V. (2003). Vynyknennia pododermatytiv u velykoi rohatoi khudoby vnaslidok travmuvannia kintsivok. Vet. medytsyna Ukrainy, 2, 29-30 (in Ukrainian).

Kurtyak, B.M. (1991). Vliyaniye faktorov soderzhaniya i kormleniya na obmen veshchestv $\mathrm{v}$ organizme telyat $\mathrm{i}$ na ikh rost. Avtoref. diss... kand. biol. nauk: 03.00.04. Lvov (in Russian).

Lebedev, P.T., \& Usovich, A.T. (2006). Metody issledovaniya kormov. organov i tkaney zhivotnykh. M.: Rosselkhozizdat (in Russian).

Lvov, B.M. (2006). Atomno-absorbtsionnyy spektralnyy analiz. M.: Nauka (in Ukrainian).

Makar, I.A. (1977). Izucheniye struktury i khimicheskogo sostava shersti: Metodicheskiye rekomendatsii. Lvov (in Russian).

Mastyko, G.S. (2005). Asepticheskiye i septicheskiye vospaleniya u selskokhozyaystvennykh zhivotnykh. Minsk: Uradzhay (in Russian).

Molokanov, V.A. (1993). Etiopatogenez. profilaktika i lecheniye zabolevaniy kopytets u krupnogo rogatogo skota v nekotorykh biogeokhimicheskikh provintsiyakh Yuzhnogo Urala: Avtoref. diss... d-ra vet. nauk. Chelyabinsk (in Russian).

Povazhenko, I.E., \& Borisevich, V.B. (1987). Bolezni konechnostey zhivotnykh. K.: Urozhay (in Russian).

Pozhyvil, A.I. (1994). Do etiolohii ta patohenezu deformovanykh kopyt u velykoi rohatoi khudoby. Visnyk s.-h. nauky, 2, 94-97 (in Ukrainian).

Rodin, V.I., \& Tyurin, V.G. (1992). Vliyaniye konstruktsii polov na zabolevaniye konechnostey zhivotnykh. Selskoye khozyaystvo za rubezhom, 12, 40-48 (in Russian).

Saievych, V.I., Hamota, A.A., \& Dutchak, I.P. (1994). Vplyv eksteriernykh vad na vynyknennia zakhvoriuvan dystalnoho viddilu kintsivok u velykoi rohatoi khudoby. Sovremennye problemy veterinarnoj hirurgii: Tez. dokl. mezhdunar. nauch.prakt. konf. Har'kov, 62 (in Ukrainian).

Vlizlo, V.I., Fedoruk, R.S., Ratych, I.B. ta in. (2012). Laboratorni metody doslidzhen $\mathrm{u}$ biolohii, tvarynnytstvi ta veterynarnii medytsyni: dovidnyk. Lviv: SPOLOM (in Ukrainian).

Yarygin, S.N. (2004). Stirayemost kopyttsevogo roga v zavisimosti ot tverdosti pola. Veterinariya, 3, 19-20 (in Russian). 